\title{
BIOGAS PRODUCTION KINETIC FROM VINASSE WASTE IN BATCH MODE ANAEROBIC DIGESTION
}

\section{Budiyono", Iqbal Syaichurrozi \& Siswo Sumardiono}

Department of Chemical Engineering, University of Diponegoro, Semarang, Indonesia - Postal Code 50239

"Corresponding Author: budiyono.1966@gmail.com

\begin{abstract}
Bottom product of distillation unit from bioethanol industry is often called as vinasse waste. Anaerobic treatment is one of good choice to convert vinasse into biogas. The purpose of this research was to study the biogas production kinetc from vinasse waste in batch mode anaerobic digestion. The kinetic model of biogas production was developed through modified Gompertz equation. Meanwhile, the kinetic of biodegradability of organic material was developed based on first order kinetic reaction. The researh resulted the kineticconstant of biogasproduction were biogas production potential (A), maximum biogas production rate $(\mathrm{U})$, and minimum time to produce biogas $(\lambda)$ of $83,982 \mathrm{~mL} /(\mathrm{kg} \mathrm{COD}), 19,71 \mathrm{~mL} /(\mathrm{kg}$ COD.day), and1.004 days, respectively. Kinetic constant of organic biodegradability material $(\mathrm{k})$ was- $0,059 \mathrm{day}^{-1}$. Kinetic model could be used to design volume of batch digesteranaerobic with the formula $\mathrm{V}_{\text {digester }}=3 * \mathrm{ym}(1-\exp (-\mathrm{k} * \mathrm{t})) * \mathrm{~m}$.
\end{abstract}

(Keywords : batch mode, biogas production, $\mathrm{COD} / \mathrm{N}$, kinetic, vinasse, bioethanol industry)

\section{INTRODUCTION}

The anaerobic digestion of waste organic materials has two advantages, i.e. treating waste and generating biogas which can be used as alternative energy source. In the anaerobic digestion, organic materials will be converted by bacteria into the biogas through four major phases i.e. hydrolysis, acidonegesis, acetonegesis and methanogenesis[1-2]. In the hydrolysis phase: complex organics (carbohydrate, protein, fat) are converted into simple organics (sugar, amino acid, LVFA); the acidonegesis phase: simple organics are converted into organic acids; the acidogenesis phase: organic acids are converted into acetic acid; the methanogenesis phase: acetic acid is converted into $\mathrm{CH}_{4}$ and $\mathrm{CO}_{2}$. Biogas contains $50-75 \% \mathrm{CH}_{4}, 25-48 \%$ $\mathrm{CO}_{2}$ and other gases in small amount [3-4].

Many authors reported that solid waste such as cattle manure, food waste, municipal solid waste [5-7] had potential to generate biogas using anaerobic digestion treatment. In addition, liquid waste such as vinasse was treated more effectively by using anaerobic treatment than that by using aerobic treatment [8-10]. Vinasse is bottom product of distillation from production ethanol by fermentation. Vinasse contains high COD, more than $100,000 \mathrm{mg} / \mathrm{L}$ [11-12].

In ethanol industry, production 1 liter ethanol will generate 8-15 liters [11,13-15]. Because of its COD content, vinasse cannot be discharged directly into the river, so the treatment of vinasse must be done and the best choice is anaerobic treatment. Espinoza-
Escalantea[8] studied the effect of initial $\mathrm{pH}$ with variation of 4.5 ; 5.5; 6.5 and the effect of digestion temperature with variation of 35 and $55^{\circ} \mathrm{C}$ to biogas production. The result showed that initial $\mathrm{pH}$ neutral (6.5) and mesophilic temperature $\left(35^{\circ} \mathrm{C}\right)$ produced the most biogas yield. Soeprijanto et al. [16] studied the effect of COD substrate with variation of 5,000; 10,000; 15,000 to biogas production.

Buitron and Carjaval [9] studied the effect of temperature and $\mathrm{HRT}$ with variation $25 ; 35^{\circ} \mathrm{C}$ and $12 ; 24$ hours respectively. From the some other authors that conducted research about production biogas from vinasse above, can be conclude that study of $\mathrm{COD} / \mathrm{N}$ ratios did not report yet. Wastewater containing COD will be destroyed and converted into biogas optimally if $\mathrm{COD} / \mathrm{N}$ of substrate in range 350/7 - 1000/7 [17].

Many authors have developed kinetic model of production biogas rate and biodegradability of organic material in anaerobic digestion. Several researchers [56,18-21] used modified Gompertz equation that was modified by Zwietering et al. [22] to make the kinetic model of biogas production. Meanwhile, Yusuf et $a l$.[23] and Yusuf and Ify [24] developed simple kinetic model of biodegradability of organic material based on the first order kinetics. This research studied the kinetic model of biogas production and kinetic model of biodegradability organic material in batch anaerobic digestion. 


\section{MATERIALS AND METHODS}

\section{Wastewater and Inoculum}

The wastewater used was vinasse obtained from an ethanol industry. The ethanol industry located in Solo, Central Java, Indonesia, that produced ethanol from molasses. Properties of vinasse that was used as biogas feedstock are shown in Table 1.

The rumen fluid was used as inoculum. In this study, rumen fluid that was in fresh condition was obtained from slaughterhouse in Semarang, Central Java, Indonesia.

Table 1: Vinasse properties

Parameters Values

COD $299,250 \pm 1.060$

TS

VS

$\mathrm{pH}$

$\mathrm{N}$
$27.865 \pm 0.000$

$284,659 \pm 0.000$

$3.25 \pm 0.212$

$1,458 \pm 0.000$

*Remarks: COD, chemical oxygen demand (mg/L); TS, total solid (\%); VS, volatile solid (mg/L), pH, power of hydrogen; $\mathrm{N}$, nitrogen content $(\mathrm{mg} / \mathrm{L})$.

\section{Preparation substrate}

In this study, substrate used was obtained from our previous study. In previous study, authors conducted investigation to know the effect of concentration of solid in substrate to biogas production. Vinasse diluted using water with ratio of vinasse:water of $1: 0 ; 1: 1 ; 1: 2$; $1: 3 ; 1 ; 4 ; 1: 5$. The result showed that substrate with ratio vinasse:water of $1: 3$ (TS $7.015 \pm 0.007 \%$ ) produced the most cumulative biogas production. Therefore, in this study, authors used substrate with ratio of vinasse:water of $1: 3$.

\section{Experimental set up}

Anaerobic digesters were made from polyethylene bottles which have a volume of $5 \mathrm{~L}$. The bottles were plugged with rubber plug and were equipped with valve for biogas measurement. Anaerobic digesters were operated in batch system and at room temperature. Biogas formed was measured by liquid displacement method as also has been used by the other authors [5, 23-24]. The anaerobic digestion of experimental laboratory set up is shown in Fig. 1.

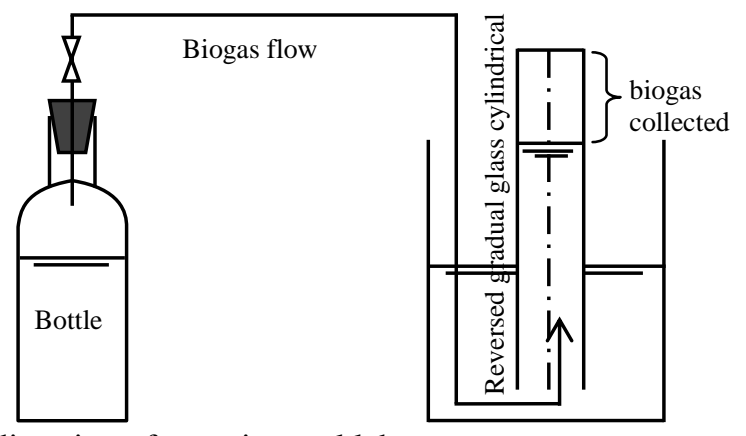

Figure 1: The batch anaerobic digestion of experimental laboratory set up 


\section{Experimental design}

Anaerobic digestions of experimental laboratory using 5-liter volumes were operated in batch system. 1-liter substrate was put in the digester. Rumen fluid as methanogenic bacteria provider that was added into the digester as much as $10 \%$ v/v substrate. From Table 1, can be known that ratio COD/N of vinasse was 1436/7.
Meanwhile, ratio $\mathrm{COD} / \mathrm{N}$ is optimum to produce biogas at range 350/7 - 1000/7 [17]. Furthermore, urea as nitrogen source was added into the digester to make $\mathrm{COD} / \mathrm{N}$ ratios of 400/7, 500/7, 600/7, 700/7. Initial pH for all variables was adjusted 7.0 by using $\mathrm{NaOH}$ solution $10 \mathrm{~N}$. The variables in this study can be seen in Table 2 .

Table 2: Variation of COD/N ratios

$\begin{array}{llcc}\text { Digester } & \text { Substrate }(\mathrm{mL}) & \begin{array}{c}\text { Rumen } \\ (\mathrm{mL})\end{array} & \mathrm{COD} / \mathrm{N}\end{array}$

\begin{tabular}{cccc}
\hline A & 1000 & 100 & $1436 / 7$ (control) \\
B & 1000 & 100 & $400 / 7$ \\
C & 1000 & 100 & $500 / 7$ \\
D & 1000 & 100 & $600 / 7$ \\
E & 1000 & 100 & $700 / 7$ \\
\hline
\end{tabular}

*Remarks: COD, Chemical Oxygen Demand; N, total nitrogen

\section{Experimental procedures}

Biogas formed was measured every once in two days to know biogas production with water displacement method (Fig 1). pH substrates in the digester were measured by $\mathrm{pH}$ meter every once in two days to know $\mathrm{pH}$ profile daily.

\section{Kinetic model of biogas production}

Biogas production kinetic was modeled through modified Gompertz equation[23]. Kinetic of biogas production in batch condition was assumed that had correspondence to specific growth rate of methanogenic bacteria in digester $[5-6,18-21,23]$. The modified Gompertz equation as follows:

$$
P=A \cdot \exp \left\{-\exp \left[\frac{U \cdot e}{A}(\lambda-t)+1\right]\right\}
$$

Where $\mathrm{P}$ is cumulative of specific biogas production $(\mathrm{mL} / \mathrm{g}$ COD $), A$ is biogas production potential $(\mathrm{mL} / \mathrm{g}$ $\mathrm{COD}), \mathrm{U}$ is maximum biogas production rate $(\mathrm{mL} / \mathrm{g}$ COD.day), $\lambda$ is lag phase period or minimum time to produce biogas (days), $\mathrm{t}$ is cumulative time for biogas production (days) and $\mathrm{e}$ is mathematical constant (2.718282). Kinetic constant of $A, \lambda$ and $U$ was determined using non-linear regression with help of polymath software [5, 20-21].

\section{Kinetic model of biodegradability of organic material}

Authors developed kinetic model of biodegradability of organic material based on first order reaction. This concept also was developed by Yusuf et al. [23] and Yusuf and Ify [24]. Assumsion: 


$$
\begin{aligned}
& \text { COD } \\
& (\mathrm{C}) \longrightarrow \quad \text { Biogas }
\end{aligned}
$$

In the first order reaction, organic material (COD, $\quad$ B) with reaction rate formula, $\mathrm{V}=-\mathrm{k}^{*} \mathrm{C}=\mathrm{k} * \mathrm{~B}$, with $\mathrm{k}$ symbolized C) was converted into biogas (symbolized = reaction rate constant.

$$
\mathrm{V}_{\mathrm{d}} \frac{d C}{d t}=\mathrm{Q}_{\mathrm{i}} * \mathrm{C}_{\mathrm{i}}-\mathrm{Q}_{\mathrm{o}} * \mathrm{C}_{\mathrm{o}}+\mathrm{V}_{\mathrm{d}}(-\mathrm{k} * \mathrm{C})
$$

In batch system, flow of input $\left(\mathrm{Q}_{\mathrm{i}}\right)=$ flow of output $\left(Q_{o}\right)=0$. Whereas $C_{i}$ and $C_{o}$ were influent and effluent

$$
\mathrm{V}_{\mathrm{d}} \frac{d C}{d t}=\mathrm{V}_{\mathrm{d}}\left(-\mathrm{k}^{*} \mathrm{C}\right)
$$

$\mathrm{COD}$ and $\mathrm{V}_{\mathrm{d}}$ was volume of digester, so that the equation (3) can be written as:

Both sides of equation (4) were divided by $\mathrm{Vd}$, so equation (4) can be written as:

$$
\begin{gathered}
\frac{d C}{d t}=(-\mathrm{k} * \mathrm{C}) \\
\frac{d C}{C}=-\mathrm{k} * \mathrm{dt} \\
\int_{C o}^{C t} \frac{d C}{C}=-\mathrm{k} \int_{0}^{t} d t \\
\ln \left(\frac{C t}{C o}\right)=-\mathrm{k} * \mathrm{t}
\end{gathered}
$$

Correlation between substrate biodegradability and biogas yield at any time $\left(\mathrm{y}_{\mathrm{t}}\right)$ can be developed assuming

$$
\begin{aligned}
& \frac{C o-C t}{C o}=\frac{y t}{y m} \\
& \frac{C o}{C t}=\frac{y m}{y m-y t}
\end{aligned}
$$

Substituting equation (5) into (7) to get (8)

$$
\ln \left(\frac{y m-y t}{y m}\right)=-\mathrm{k} * \mathrm{t}
$$

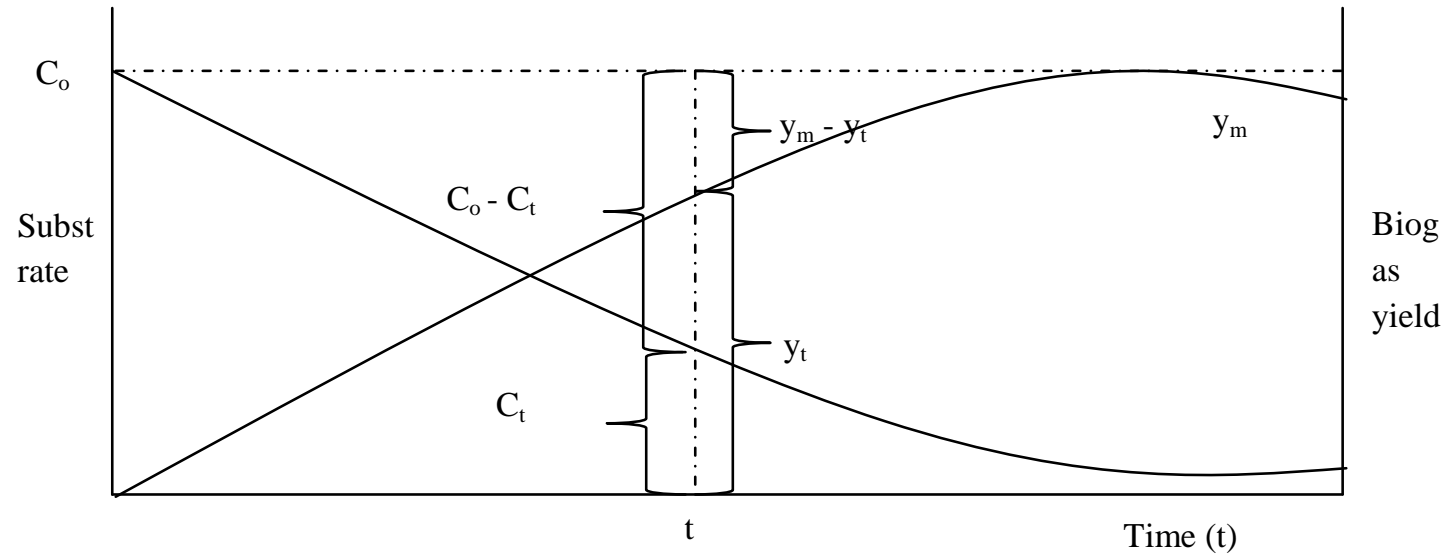

Figure 2: Subtrate transformation into biogas during anaerobic degradation
Biog yield 
Rearrange (8) to get (9)

$$
\begin{array}{r}
\frac{y m-y t}{y m}=\exp \left(-\mathrm{k}^{*} \mathrm{t}\right) \\
\operatorname{ym}\left(1-\exp \left(-\mathrm{k}^{*} \mathrm{t}\right)\right)=\mathrm{yt}
\end{array}
$$

From equation (9); ym, volume of biogas formed at maximum time $(\mathrm{mL} / \mathrm{kg} \mathrm{COD})$; yt, volume of biogas formed at any time (t); - $\mathrm{k}$, rate constant associated with

$$
\begin{gathered}
\mathrm{yt}=\mathrm{ym}(1-\exp (-\mathrm{k} * \mathrm{t})) \\
\frac{d y t}{d t}=0-(-\mathrm{k}) * \mathrm{ym} * \exp (-\mathrm{k} * \mathrm{t}) \\
\frac{d y t}{d t}=\mathrm{k} * \mathrm{ym} * \exp (-\mathrm{k} * \mathrm{t})
\end{gathered}
$$

Taking natural logarithm on both sides of the equation (10)

$$
\begin{array}{r}
\ln \left(\frac{d y t}{d t}\right)=\ln (\mathrm{k} * \mathrm{ym} * \exp (-\mathrm{k} * \mathrm{t}) \\
\ln \left(\frac{d y t}{d t}\right)=(\ln \mathrm{ym}+\ln \mathrm{k})-\mathrm{k} * \mathrm{t} \\
\frac{1}{t} \ln \left(\frac{d y t}{d t}\right)=\frac{1}{t}(\ln \mathrm{ym}+\ln \mathrm{k})-\mathrm{k}
\end{array}
$$

Equation (11) represented straight line equation $y=m x$ $+\mathrm{c}$. Slope of straight line equation $(\mathrm{m})$ represented the value of $(\operatorname{lnym}+\ln \mathrm{k})$ and intercept of that (c) represented the value of $(-\mathrm{k})$.

\section{RESULTS AND DISCUSSIONS}

\section{Effect of COD:N ratio to kinetic model of biogas production}

Biogas production for all variables was modeled based on modified Gompertz equation. Kinetic constant of A, $\mathrm{U}$ and $\lambda$ was determined by using non-linear regression. Kinetic constants obtained were presented completely in Table 3. By plotting experimental data and simulation of modified Gompertz equation was obtained the graph as shown in Fig 3.
From Table 3., difference in the COD:N ratio affected value of kinetic constant. Control variable had the lowest value of A which was $33,429 \mathrm{~mL} / \mathrm{kg}$ COD. That means control variable in prediction generated biogas in little amount. Meanwhile, variable with $\mathrm{COD} / \mathrm{N}$ of $600 / 7$ had the highest value of A which was 109,368 $\mathrm{mL} / \mathrm{kg}$ COD.

Variable that had optimum COD/N ratio caused good condition for bacterial growth in the digester so that biogas will be generated maximally. COD/N ratio of substrate is necessary parameter in anaerobic treatment, optimum COD/N ratio is in range of 350/7 - 1000/7. If $\mathrm{COD} / \mathrm{N}$ is out from that range, bacterial growth will be disturbed [17]. Nitrogen was needed by bacteria to build cell structures [26-27]. 
Table 3: Kinetic constant of biogas production

\begin{tabular}{|c|c|c|c|c|c|}
\hline \multirow{2}{*}{ Variable } & \multirow{2}{*}{$\begin{array}{l}\text { Total of Biogas Volume } \\
\qquad(\mathrm{mL} / \mathrm{kg} \mathrm{COD})\end{array}$} & \multicolumn{3}{|c|}{ Modified Gompertz Equation (Model) } & \multirow{2}{*}{$\mathrm{R}^{2}$} \\
\hline & & $\mathrm{A}(\mathrm{mL} / \mathrm{kg} \mathrm{COD})$ & $\mathrm{U}$ (mL/kg COD. day) & $\lambda$ (day) & \\
\hline Control & $33,591.78$ & 33,429 & 24,165 & 1.505 & 0.998 \\
\hline $400 / 7$ & $94,376.29$ & 91,354 & 19,954 & 1.255 & 0.986 \\
\hline $500 / 7$ & $110,550.60$ & 108,444 & 20,156 & 0.908 & 0.991 \\
\hline $600 / 7$ & $111,649.80$ & 109,368 & 23,466 & 0.803 & 0.988 \\
\hline $700 / 7$ & $77,233.62$ & 76,712 & 10,807 & 0.572 & 0.991 \\
\hline & onstant average & 83,982 & 19,71 & 1.004 & 0.991 \\
\hline
\end{tabular}

Remarks: A, biogas production potential; $\mathrm{U}$, maximum biogas production rate; $\lambda$, minimum time to produce biogas; $\mathrm{R}^{2}$, correlation coefficient.

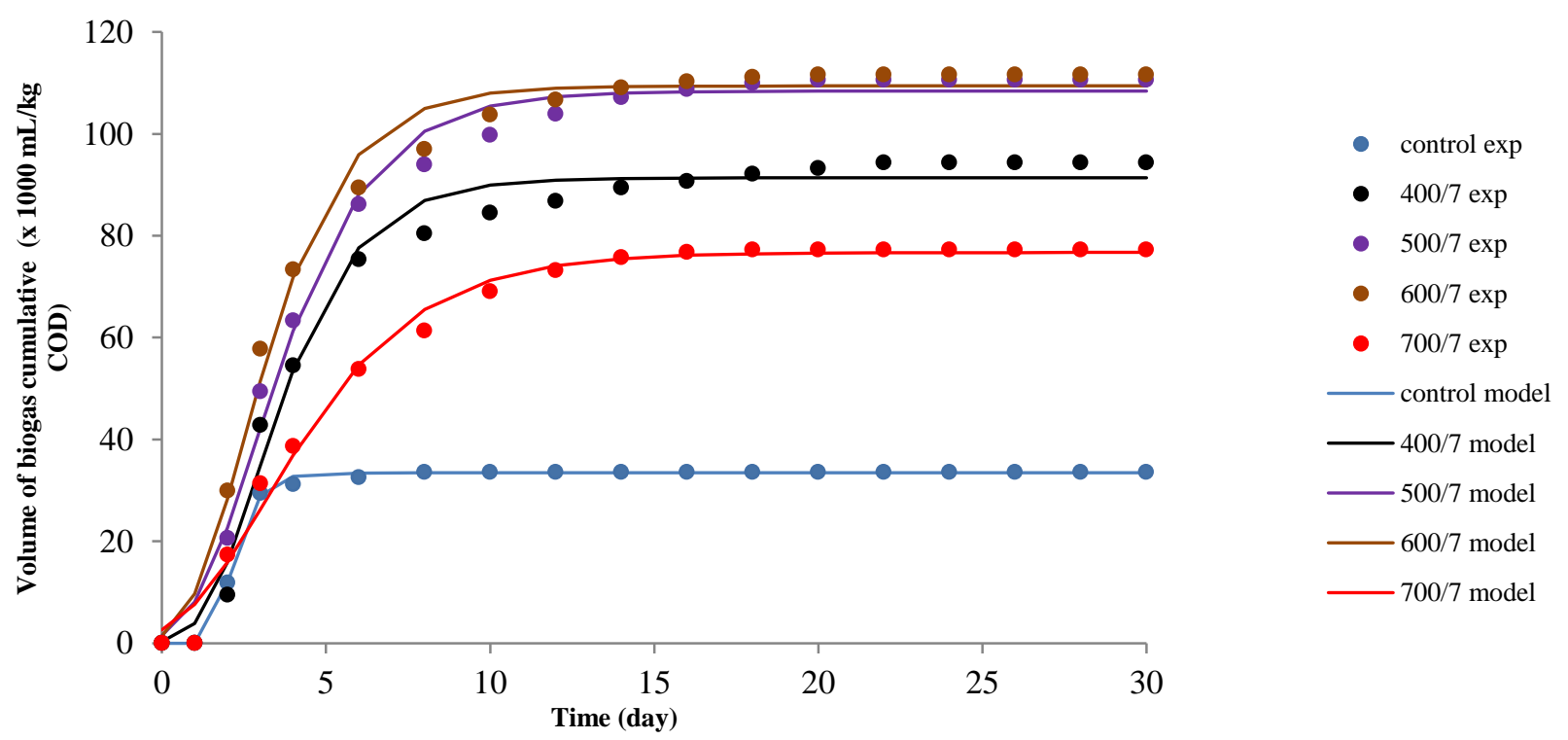

Remarks: exp, data from experiment data; model, data from modified Gompertz model

Figure 3: Comparison of experimental data and modified Gompertz model

Variable with COD/N of 400/7 and 700/7 had more value of $\mathrm{A}$ constant and produced more biogas than control variable. In control variable, $\mathrm{COD} / \mathrm{N}$ ratio was not appropriate, the amount of nitrogen total in substrate was too little so that bacteria could not build cell structures and finally death. On the other hand, variable with $\mathrm{COD} / \mathrm{N}$ of $400 / 7$ and $700 / 7$ had less value of A constant than that of 500/7 and 600/7.

Protein and urea in the substrate was decomposed to be ammonia/ammonium. Ammonia/ammonium was used by bacteria as nitrogen source [28] but ammonia/ammonium in large amount became toxic to 
bacterial activity. De-Baere et al. [29] reported that concentration of ammonia of 100-140 mg/L hampered bacterial growth in mesophilic temperature. Omil et al. [30] stated that ammonia with concentration $25 \mathrm{mg} / \mathrm{L}$ was minimum concentration that disturbed bacterial activity. Meanwhile according to Deublein and Steinhauser [31], ammonia concentration of $80 \mathrm{mg} / \mathrm{L}$ was minimum concentration to disturb bacterial growth and $150 \mathrm{mg} / \mathrm{L}$ was toxic to bacteria.Methanogenic bacteria was the least tolerant and the most easily killed to ammonia inhibition among the four anaerobic bacteria in four step biogas production there were hydrolysis, acidogenesis, acetogenesis, methanogenesis.

Ammonia $\left(\mathrm{NH}_{3}\right)$ formedammonium $\left(\mathrm{NH}_{4}{ }^{+}\right)$depend on $\mathrm{pH}$ condition. Ammonium had less toxic than ammonia. Ammonium will be toxic just in high concentration. Ammonium concentration of 1,500-10,000 mg/L was inhibition start and that of $30,000 \mathrm{mg} / \mathrm{L}$ was toxicity concentration [31].

Substrate with COD/N ratio of 400/7 might contain nitrogen total that was too much, so that ammonia/ammonium formed caused toxicity for bacterial activity. Whereas, substrate with $\mathrm{COD} / \mathrm{N}$ ratio of $700 / 7$ contained nitrogen total that was not in appropriate amount yet.Although, COD/N of 400/7 and $700 / 7$ was included in optimum range that was stated by Speece [17]. The good COD/N ratio in this study was 500/7 - 600/7.

From Table 3, the $\mathrm{U}$ constant value of control variable was the highest of all variables, which was 24,165 $\mathrm{mL} / \mathrm{kg}$ COD.day. That was caused by cumulative time that needed to produce biogas. Control variable produced biogas just until $8^{\text {th }}$ day fermentation (Fig 3.), whereas the other variables generated biogas until up to $15^{\text {th }}$ day of fermentation. Although control variable had value of $U$ constant was highest, it had value of A was lowest because biogas production process took in short time.

Control variable had high value of $\lambda$. Budiyono et al. [5] stated that variable that had little value of kinetic constant of $\lambda$, needed just little time to produce biogas. Zwietering et al. [22] reported that value of $\lambda$ indicated the time that was required for bacteria to adapt. Based on that, bacteria in control variable needed much time to adapt and produce biogas which was 1.505 days. Whereas, variable with $\mathrm{COD} / \mathrm{N}$ ratio of $400 / 7$, 500/7, 600/7, 700/7 needed less time than control variable. Bacteria needed nitrogen to build cell structures, so availability of nitrogen in appropriate amount caused good growth of bacteria in digester. If bacteria is not lack of nutrient, degradation activity is done well and biogas will be generated immediately.

\section{Effect of COD:N ratio to kinetic model of biodegradability of organic material}

From equation (11), we had straight line equation $\frac{1}{t} \ln \left(\frac{d y t}{d t}\right)=\frac{1}{t}(\ln \mathrm{ym}+\ln \mathrm{k})-\mathrm{k}$. The value of $\mathrm{k}$ obtained by plotting $\frac{1}{t} \ln \left(\frac{d y t}{d t}\right)$ against $\frac{1}{t}$. The results of plotting that can be seen in Fig. 4. Yusuf et al. [23] stated that the term (-k) was a measure of the rate of removal of the biodegradable fractions as the biogas yield increased with time. This rate constant was an aspect of the first order rate constant. The more negative the value of $(-k)$, the faster the rates of removal of the biodegradable fractions. The value of (-k) for control, $400 / 7,500 / 7,600 / 7,700 / 7$ was $(-0.6466),(-0.1852),(-$ $0.2365),(-0.2876),(-0.2355)$ respectively with good value of $R^{2}$ in range $0.9867-0.9996$.

From Figure 4, the most negative of (-k) value was in control variable but it generated the least biogas total. Bacteria in control variable generated biogas in large amount at beginning fermentation. This was caused by characteristic of vinasse. Vinasse contained simple organic materials such as acetic acid, lactic acid and glycerol [32], so that bacteria could easily degrade them into biogas. After $8^{\text {th }}$ day, biogas was not generated. Meanwhile in variable with COD/N ratio of 400/7 $700 / 7$, biogas was generated biogas in large amount at beginning (at $2^{\text {nd }}-3^{\text {rd }}$ day), then decreased until $18^{\text {th }}-$ $22^{\text {nd }}$ day. In control variable, the process of decreasing of biogas production took the shortest time of all variable so that biodegradability rate was high although biogas formed was little. Biogas production daily can be seen in Fig 5. 


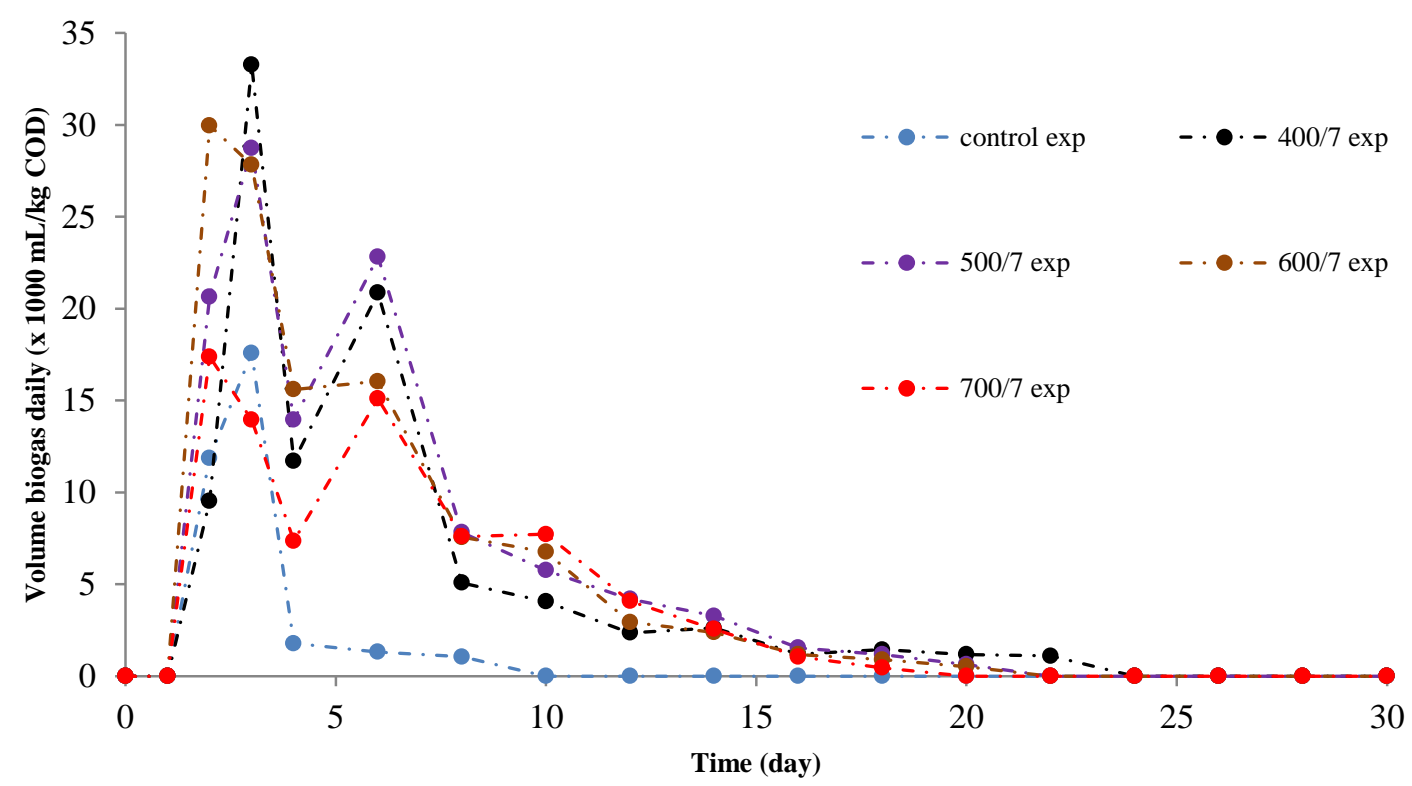

Figure 5: Volume biogas daily (experiment)

Among of COD/N ratio with variation of 400/7, 500/7, $600 / 7$ and $700 / 7, \mathrm{COD} / \mathrm{N}$ of $600 / 7$ had the most negative of $(-\mathrm{k})$ value which was $(-0.2876)$. That means organic material (COD) that was contained in substrate, was faster to be degraded than that in the other variables. COD/N of 600/7 also had the highest value of biogas production potential constant (A). Yusuf et al. [23] reported that the more negative of $(-k)$ value was obtained from first order model, the more biogas production potential (A) was obtained from modified Gompertz model. In this study, variable with COD/N ratio of 500/7 and 600/7 that had the most value of $\mathrm{A}$ (108,444 and 109,368 mL/kg COD respectively) had the most negative of $\mathrm{k}$ value $(-0.2365$ and -0.2876 /day respectively), so this result was similar with the result of Yusuf et al. [23].
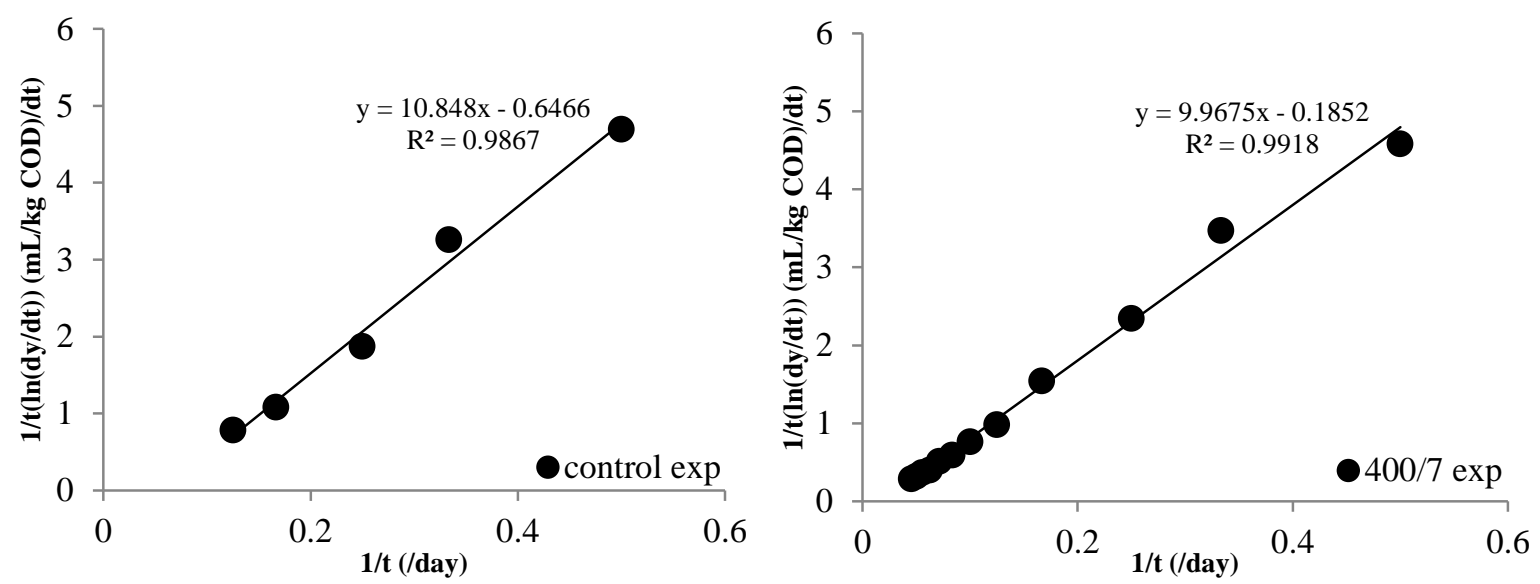

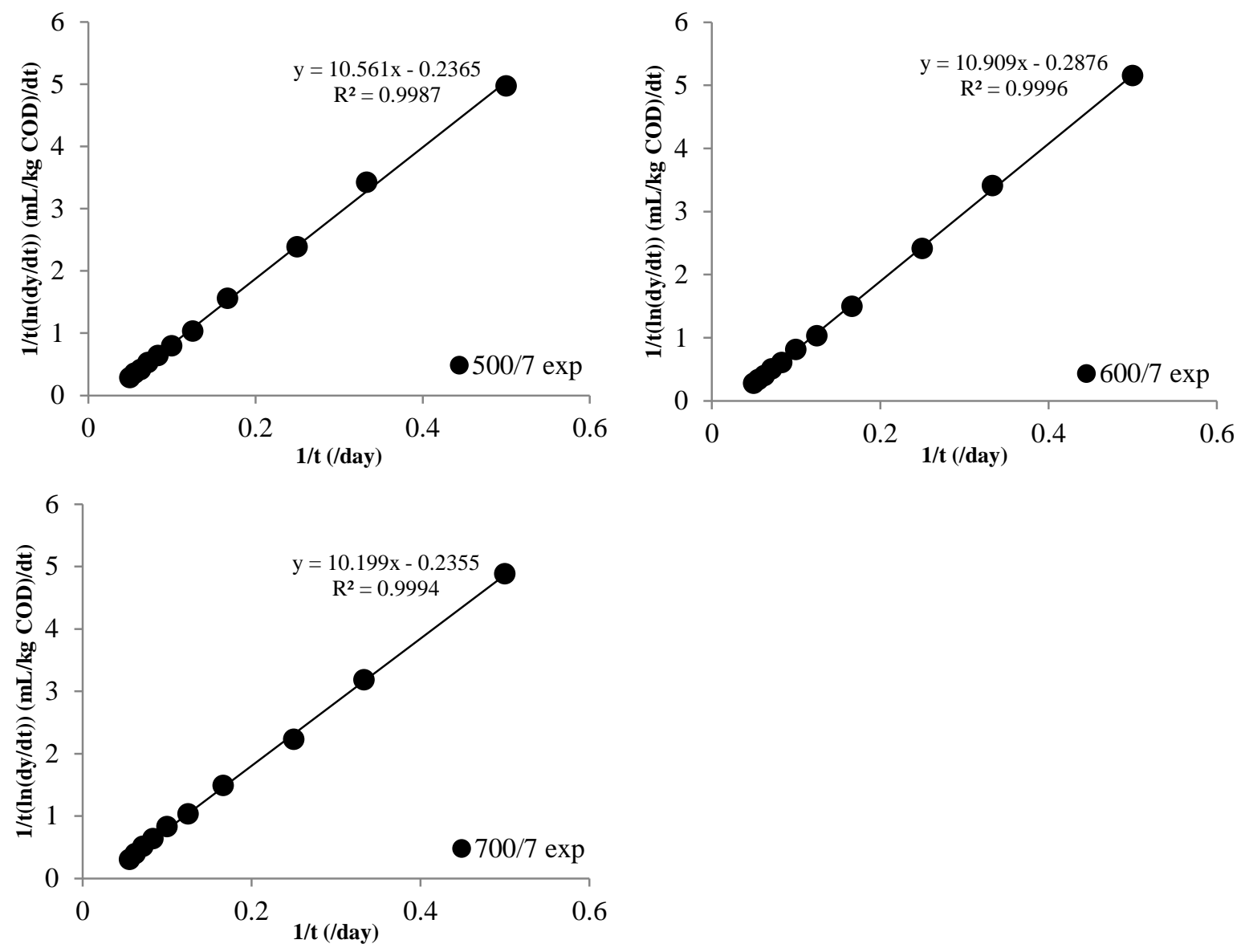

*Remark: exp, based on experiment data

Figure 4: Plot of 1/t $(\ln (\mathrm{dy} / \mathrm{dt}))(\mathrm{mL} / \mathrm{kg} \mathrm{COD} / \mathrm{dt})$ against $1 / \mathrm{t}(/ \mathrm{day})$

\section{pH profile}

$\mathrm{pH}$ profile for all variables is shown in Fig 6 . Elbeshbishy and Nakhla [33] stated that decreasing of $\mathrm{pH}$ was caused by VFAs (organic acid) production at beginning of fermentation. Vinasse used in this study was obtained from ethanol industry that produced ethanol from molasses. Ethanol was produced by fermentation yeast. Ethanol formed was separated from fermentation broth by distillation. The bottom product of distillation process was vinasse. Therefore, vinasse contained short chain molecular that was easy to be degraded by bacteria into VFAs (organic acid) so $\mathrm{pH}$ medium was easy to drop.

Deublein and Steinhauser [31] reported that there were two kinds of organic acid which were dissociated and not-dissociated acid. Composition of them in substrate was depended by $\mathrm{pH}$ condition. The more acidic of $\mathrm{pH}$ substrate, the more amount of not-dissociated acid was in substrate. Presence of not-dissociated acid hampered bacterial activity, because it was penetrated into cell through cell membrane and then spoiled the protein of bacteria. 


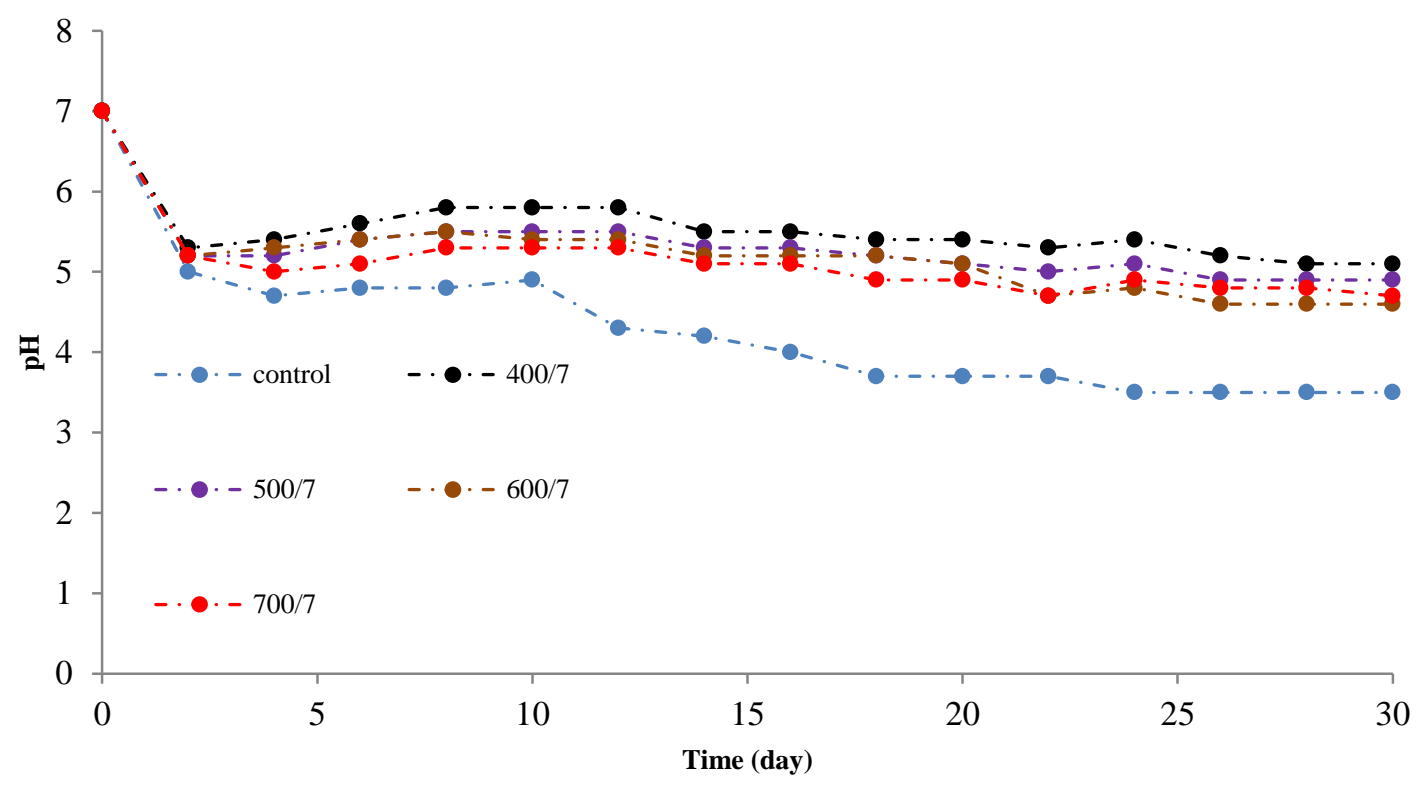

Figure 6: $\mathrm{pH}$ profile

Profile of $\mathrm{pH}$ for all variables showed that decreasing $\mathrm{pH}$ from beginning until ending of fermentation. Control variable had the sharpest trend of decreasing $\mathrm{pH}$ substrate of all variables. This phenomenon was caused by presence of total nitrogen. According to Mata-Alvarez et al. [34], substrate contained carbohydrate in large amount potentially produced VFAs that caused acidity in $\mathrm{pH}$. Whereas substrate that contained nitrogen in large amount potentially produced $\mathrm{NH}_{4}{ }^{+}$that caused alkalinity in $\mathrm{pH}$.

Elbeshbishy and Nakhla [33] reported that decreasing in the $\mathrm{pH}$ could be due to the rapid VFAs production at the beginning, while the increasing in the $\mathrm{pH}$ from $3^{\text {rd }}$ day to $10^{\text {th }}$ day could be due to generation of $\mathrm{NH}_{4}{ }^{+}$ during protein degradation, as ammonia which was a base combines with carbon dioxide and water to form ammonium bicarbonate (a natural pH buffer). However, in this experiment, $\mathrm{pH}$ decreased until the end (Fig 6). This phenomena was caused accumulation of VFAs production in the digester was very large. Condition of $\mathrm{pH}$ in the substrate was very acid and methanogenic bacteria was death. Ammonium production from degradation urea and protein could not increase the $\mathrm{pH}$ because VFAs was produced rapidly.

\section{Design of anaerobic batch digester using kinetic model}

Yusuf and Ify[24] designed batch digester to treat cow dung, waste paper and water hyacinth. A ratio of volume gas chamber:volume of anaerobic digester of 1:3 was used by Yusuf and Ify [24] and Igoni et al.. [35]as establishing basic to design batch digester. Volume gas chamber $\left(\mathrm{V}_{\mathrm{gc}}\right)$ was proportional to the volume of biogas formed.

$$
\begin{aligned}
& \mathrm{V}_{\mathrm{gc}}=1 / 3 \mathrm{~V}_{\text {digester }} \\
& 3 \mathrm{~V}_{\mathrm{gc}}=\mathrm{V}_{\text {digester }}
\end{aligned}
$$

$\mathrm{V}_{\mathrm{gc}}(\mathrm{mL})=\mathrm{yt}(\mathrm{mL} / \mathrm{kg} \mathrm{COD}) * \mathrm{~m}$ (mass of COD fed into the digester),

$$
\begin{aligned}
& \text { And from equation (9), we had } \\
& \mathrm{yt}=\mathrm{ym}\left(1-\exp \left(-\mathrm{k}^{*} \mathrm{t}\right)\right)
\end{aligned}
$$

Subtituting equation (13) into (12)

$$
\mathrm{V}_{\text {digester }}=3 * \mathrm{yt} * \mathrm{~m}
$$


And, substituting equation (9) into (14)

$$
\mathrm{V}_{\text {digester }}=3 * \mathrm{ym}(1-\exp (-\mathrm{k} * \mathrm{t})) * \mathrm{~m}
$$

ym was volume of biogas formed at maximum time $(\mathrm{mL} / \mathrm{kg} \mathrm{COD})$, so we can replace value of ym with kinetic constant A which was 109,368 mL/kg COD (in variable with $\mathrm{COD} / \mathrm{N}$ of 600/7). Assuming we want to treat $10 \mathrm{~L}$ vinasse that contained $299,250 \mathrm{mg} / \mathrm{L} \mathrm{COD}$, so substrate contained 2,992,500 $\mathrm{mg}$ COD $=2.992 \mathrm{~kg}$.
Retention time that was needed based on Fig 5. was 20 days. So $\mathrm{V}_{\text {digester }}=3 * 109,368 \mathrm{~mL} / \mathrm{kg}$ COD $(1-\exp (-$ $0.2876 /$ day $* 20$ days) $) * 2.992 \mathrm{~kg}$. Thus, $\mathrm{V}_{\text {digester }}=$ $978568 \mathrm{~mL}=978.6$ Liter. Detail calculation of $\mathrm{V}_{\text {digester }}$ for all variables can be seen in Table 4.

Table 4: Calculation of digester volume for treat $10 \mathrm{~L}$ vinasse (contains $299,250 \mathrm{mg} / \mathrm{L} \mathrm{COD}$ )

\begin{tabular}{cccccc}
\hline Variable & $\begin{array}{c}\mathrm{m} \\
(\mathrm{kg} \mathrm{COD})\end{array}$ & $\begin{array}{c}\mathrm{A} \\
(\mathrm{mL} / \mathrm{kg} \mathrm{COD})\end{array}$ & $\begin{array}{c}-\mathrm{k} \\
(/ \mathrm{day})\end{array}$ & $\begin{array}{c}\mathrm{t} \\
(\text { based on Fig 5) }(\text { day })\end{array}$ & $\begin{array}{c}\mathrm{V}_{\text {digester }} \\
(\text { Liter })\end{array}$ \\
\hline Control & 2.992 & 33,429 & -0.6466 & 8 & 298.4 \\
$400 / 7$ & 2.992 & 91,354 & -0.1852 & 22 & 806.1 \\
$500 / 7$ & 2.992 & 108,444 & -0.2365 & 20 & 964.8 \\
$600 / 7$ & 2.992 & 109,368 & -0.2876 & 20 & 978.6 \\
$700 / 7$ & 2.992 & 76,712 & -0.2355 & 18 & 678.6
\end{tabular}

Remarks: m, mass of COD fed into digester; A, biogas production potential; -k, biodegradability rate of COD; $\mathrm{t}$, retention time

\section{CONCLUSION}

Variation of $\mathrm{COD} / \mathrm{N}$ ratio affected value of kinetic constant on kinetic model of biogas production that was modeled through modified Gompertz model. Variable with $\mathrm{COD} / \mathrm{N}$ of $600 / 7$ that was the best variable, had the values of $\mathrm{A}$ (biogas production potential), $\mathrm{U}$ (maximum biogas production rate) and $\lambda$ (minimum time to produce biogas) which were $109,368 \mathrm{~mL} / \mathrm{kg}$ COD; 23,466 mL/kgCOD.day; 0.803 day. On kinetic model of biodegradability of organic material, variable with $\mathrm{COD} / \mathrm{N}$ of $600 / 7$ had the most negative value of (k) (biodegradability rate constant, $-0.2876 /$ day), that means organic material of substrate that had $\mathrm{COD} / \mathrm{N}$ of $600 / 7$ was easy to be degraded by bacteria. Volume of digester could be designed with formula of $\mathrm{V}_{\text {digester }}=3$ * ym $(1-\exp (-\mathrm{k} * \mathrm{t})) * \mathrm{~m}$.

\section{REFERENCES}

[1] Batstone, D.J., J. Keller, I. Angelidaki, S.V. Kalyuzhnyi, S.G. Pavlostathis, A. Rozzi, W.T.M. Sanders, H. Siegrist andV.A. Vavilin,
2002. The IWA Anaerobic Digestion Model No 1 (ADM1). Water SciTechnol,45:65-73.

[2] Esposito, G., L. Frunzo, A. Panico and F. Pirozzi, 2011. Modelling the Effect of the OLR and OFMSW Particle Size on the Performances of an Anaerobic Co-digestion Reactor. J Process Biochem,46:557-565.

[3] Juanga, J.P., C. Visvanathan and J. Tränkler, 2007. Optimization of Anaerobic Digestion of Municipal Solid Waste in Combined Process and Sequential Staging. J Waste Manage Res, 25:30-38.

[4] Karellas, S.B, 2010. Development of an investment decision tool for biogas production from agricultural waste. Jurnal Renewable and Sustainable Energy Reviews, 14:1273-1282.

[5] Budiyono, I.N. Widiasa, S. Johari and Sunarso, 2010. The Kinetic of Biogas Production Rate from Cattle Manure in Batch Mode. International Journal of Chemical and Biological Engineering, 3(1):39-44.

[6] Zhu, B., P. Gikas, R. Zhang, J. Lord, B. Jenkins, and X. Li, 2009. Characteristics and 
Biogas Production Potential of Municipal Solid Wastes Pretreated with a Rotary Drum Reactor. Bioresource Technology, 100:1122-1129.

[7] Shin, J.D., S.S. Han, K.C. Eom, S. Sung, S.W. Park andH. Kim, 2008. Predicting Methane Production Potential of Anaerobic Co-Digestion of Swine Manure anf Food Waste. Environ. Eng. Res., 13(2):93-97.

[8] Espinoza-Escalante, F.M., C. Pelayo-Ortız, J. Navarro-Corona, Y. Gonzalez-Garcia, A. Bories, and H. Gutierrez-Pulido, 2009. Anaerobic digestion of the vinasses from the fermentation of Agave tequilana Weber to tequila: The effect of $\mathrm{pH}$, temperature and hydraulic retention time on the production of hydrogen and methane. Journal Biomass and Bioenergy, 33:14-20.

[9] Buitron, G., andC. Carvajal, 2010. Biohydrogen Production from Tequila Vinasse in an Anaerobic Sequencing Batch Reactor: Effect of Initial Substrate Concentration, Temperature, and Hydraulic Retention Time. Bioresource Technology, 101:9071 - 9077.

[10] Siles, J.A., I. García-García, A. Martín and M.A. Martín, 2011. Integrated ozonation and biomethanization treatments of vinasse derived from ethanol manufacturing. Journal of Hazardous Materials, 188:247-253.

[11] Robles-Gonzalez, V., E. Lopez-Lopez, F. Martinez-Jeronimo, A. Ortega-Clemente, N. Ruiz-Ordaz, J. Galindez-Mayer, N. Rinderknecht-Seijas andH.M. Poggi-Varaldo, 2010. Combined treatment of mezcalvinasses by ozonation and aerobic biological posttreatment. Procedings of 14th International Biotechnology Symposium. Rimini, Italy, 1418, September 2010.

[12] Lutoslawki, K., A. Ryznar-Luty, E. Cibis, M. Krzywonos and T. Miskiewicz, 2011. Biodegradation of beet molasses vinasse by a mixed culture of microorganisms: Effect of aeration conditions and $\mathrm{pH}$ control. Journal of Environmental Sciences, 23(11):1823-1830.

[13] Garcia-Garcia, I., J.L. Bonilla-Venceslada, P.R. Jimenez-Pena, E. Ramos-Gomez, 1997. Biodegradation of phenol compounds in vinasse using aspergillusterreus and geotrichumcandidum. War. Res., 31(8):20051011.

[14] Jimenez, A.M., R. Borja, A. Martin and F. Raposo, 2005. Mathematical modelling of aerobic degradation of vinasses with Penicilliumdecumbens. Process Biochem, 40:2805-2811.

[15] Preeti, C.S. andB.P. Aniruddha, 2006. Enhancement in biodegradability of distillery wastewater using enzymatic pretreatment. J. Environ. Manage, 78(1):77-85.

[16] Soeprijanto, T. Ismail, M.D. Lastuti and B. Niken, 2010. Treatment of VinasseFrom Alcohol Industry Wastewater Into Biogas Using Upflow Anaerobic Sludge Blanket (UASB) Bioreactor. JurnalPurifikasi, 11(1):11-20.

[17] Speece, R.E., 1996. Anaerobic Technology for Industrial Wastewaters. USA: Archae Press.

[18] Elaiyaraju, P. andN. Partha, 2012. Biogas Production from Co-Digestion of Orange Peel Waste and Jatropha De-Oiled Cake in an Anaerobic Batch Reactor. African Journal of Biotechnology, 11(14):3339-3345.

[19] Nopharatana, A., P.C. Pullammanappallil and W.P. Clarke, 2006. Kinetics and Dynamic Modelling of Batch Anaerobic Digestion of Municipal Solid Waste in a Stirred Reactor. http://www.sciencedirect.com/science/article/pii /S0956053X06001346 (On line June 12 2013).

[20] Patil, J.H., M.A. Raj, P.L. Muralidhara, S.M. Desai and G.K.M. Raju, 2012. Kinetics of Anaerobic Digestion of Water Hyacinth Using Poultry Litter as Inoculum. International Journal of Environmental Science and Development, 3(2):94-98.

[21] Adiga, S., R. Ramya, B.B. Shankar, J.H. Patil and C.R. Geetha, 2012. Kinetics ofAnaerobic Digestion of Water Hyacinth, Poultry Litter, Cow Manure and Primary Sludge: A Comparative Study. International Conference on Biotechnology and Environment Management $2^{\text {nd }}, 14: 73-78$.

[22] Zwietering, M.H., I. Jongenburger, F.M. Rombouts and van'tRiet, 1990. Modelling the Bacterial Growth Curve. Applied and Environmental Microbiology, 56(6):1875-1881.

[23] Yusuf, M.O.L., A. Debora and D.E. Ogheneruona, 2011. Ambient temperature kinetic assessment of biogas production from co-digestion of horse and cow dung. Res. Agr. Eng., 57(3):97-104.

[24] Yusuf, M.O.L. and N.L. Ify, 2011. The effect of waste paper on the kinetics of biogas yield from the co-digestion of cow dung and water hyacinth. Biomass and Bioenergy, 35:13451351.

[25] Linke, B., 2006. Kinetic study of thermophilic anaerobic digestion of solid wastes from potato processing. Biomass Bioenergy, 30:892-896.

[26] Angelidaki, I. and B.K. Ahring, 1993 Thermophilic anaerobic digestion of livestock waste: the effect of ammonia. ApplMicrobiolBiotechnol, 38(4):560-564.

[27] Fang, H.H.P., H.K. Chui, Y.Y. Li andT. Chen, 1994. Performance and granule characteristics 
of UASB process treating wastewater with hydrolyzed proteins. Water SciTechnol, 30(8):55-63.

[28] Sung, S. and T. Liu, 2003. Ammonia inhibition on thermophilic anaerobic digestion. Chemosphere, 53(1):43-52.

[29] De-Baere, L.A., M. Devocht, P. Van Assche, and W. Verstraete, 1984. Influence of high $\mathrm{NaCl}$ and $\mathrm{NH} 4 \mathrm{Cl}$ salt levels on methanogenic associations. Water Res., 18:543-548.

[30] Omil, F., R. Mendez andJ.M. Lema, 1995. Anaerobic treatment of saline wastewaters under high sulphide and ammonia content. Bioresour. Technol., 54:269-278.

[31] Deublein, D. and A. Steinhauser, 2008. Biogas from Waste and Renewable Resources. Weinheim: Wiley-VCH Verlag.
[32] Yavuz, Y., 2007. EC and EF processes for the treatment of alcohol distillery wastewater. Sep. Purif. Technol., 53:135-140.

[33] Elbeshbishy, E. and G. Nakhla, 2012. Batch anaerobic co-digestion of proteins and carbohydrates. Bioresource Technology, 116:170-178.

[34] Mata-Alvarez, J., S. Mace, P. Llabres, 2000. Anaerobic digestion of organic wastes. An overview of research achievements and perspectives. Bioresour. Technol., 74:3-16.

[35] Igoni, A.H., M.F.N. Abowei, J.M. Ayotamuno, L.E. Chibuogwo, 2007. Effect of total solids concentration of municipal solid waste in anaerobic batch digestion on the biogas produced. J Food Agric Environ, 5(2):333-337. 